\title{
CHARACTER BUILDING OF STUDENTS WITH COUNSELING SERVICES APPROACH
}

\author{
Nurul Atieka \\ Universitas Muhammadiyah Metro
}

\begin{abstract}
Expectations of society, which until now has not significantly met by the world of education in Indonesia, it becomes a challenge to improve the quality of education. The rise of the brawl, the case of drugs and free sex among students makes people pessimistic about the quality of education and educational output. Associated with the various problems that come across, character building of young generation ago into something that absolutely must be done. An understanding of identity, duties, and responsibilities of students, and also habituation to the values and norms in the community becomes a necessity that must be installed. Counseling services as a form of education play a major role in providing assistance to students in order to achieve optimal development. Achieving optimal developmental tasks, and effectively became the foundation of character formation of students and the fulfillment of the expectations of society toward education.
\end{abstract}

Keyword: Character, Counseling Services, Education

\section{PENDAHULUAN}

Perhatian yang sangat besar dari semua elemen masyarakat kepada dunia pendidikan menjadi sebuah tantangan tersendiri bagi stakeholder pendidikan. Ekspekstasi masyarakat terhadap luaran pendidikan salah satunya adalah generasi yang mampu menjadi pe"ubah" (agent of change) dan solusi terhadap segala persoalan yang muncul pada bangsa Indonesia.
Realita yang terjadi pada dunia pendidikan Indonesia saat ini bukannya menjadikan masyarakat optimis terhadap luaran dan proses pendidikan, namun sebaliknya. Masyarakat menjadi pesimis dan ragu akan kualitas luaran pendidikan. Memang, jika hanya ditinjau dari aspek kognitif dan/atau akademik peserta didik Indonesia sudah terbilang cukup maju. Banyak peserta didik Indonesia menjadi juara olimpiade Sains internasional, menemukan dan 
melakukan inovasi terhadap teknologi. Namun disisi lain, masyarakat sering kali dibuat prihatin dan miris dengan peserta didik di Indonesia. Kasus tawuran yang sampai menelan korban jiwa, perilaku seks bebas, narkoba, dan kriminalitas seakan-akan saat ini identik dengan dunia pendidikan dan kaum terpelajar Indonesia.

Lalu, apa yang salah dalam dunia pendidikan kita? Kita akan sepakat jika menjawab bahwa selama ini proses pendidikan kita cenderung "mengagung-agungkan" nilai dan prestasi akademik sebagai tujuan akhir proses pendidikan. Tidak dipungkiri nilai atau prestasi akademik adalah hal yang penting, akan tetapi lebih dari itu kesuksesan hidup manusia bukan hanya terletak pada aspek kognitif semata. Keberhasilan manusia sangat didukung dengan kemajuan dan kesuksesan pada semua aspek, baik kognitif, afektif, dan psikomotorik. Jika pendidikan terlalu diorientasikan pada aspek kognitif, maka yang terjadi siswa akan rendah nilai toleransi dengan sesama, tidak peka terhadap perbedaan, anti-sosial, dan cenderung bersifat individualis.

$\begin{array}{rcr}\text { Upaya } & \text { merubah } & \text { paradigma } \\ \text { pendidikan } & \text { yang } & \text { hanya }\end{array}$

mengembangkan kemampuan kognitif peserta didik menjadi sesuatu urgen pada kondisi saat ini. Merujuk kepada pendapat Nurul Zuriah (2011) alasan mendasar mengapa saat ini perlu pendidikan moral, budi pekerti, dan karakter adalah karena melemahnya ikatan keluarga, kecenderungan negatif di dalam nkehidupan remaja yang semakin memprihatinkan, dan mulai timbulnya kesadaran masyarakat akan perlunya nilai-nilai etik, moral, dan budi pekerti dalam perikehidupannya.

Mengembangan karakter peserta didik merupakan proses yang bisa dilatihkan, diajarkan, dan dibentuk. Sebagai proses pendidikan, pelayanan konseling memiliki kapasitas dan kapabilitas mengembangkan karakter peserta didik. Melalui proses pelayanan yang berorientasi pada pemberdayaan semua aspek individu, unik, dan dilakukan dengan prinsip keahlian adalah alasan pelayanan konseling menjadi alternative utama mengembangkan karakter peserta didik melalui proses pendidikan sekolah.

\section{PEMBAHASAN}

\section{a. Pengertian Karakter}

Pengembangan karakter peserta didik sejatinya proses yang lebih 
kompleks daripada membangun intelektual. Membangun karakter terkait erat dengan perilaku dan melibatkan semua domain pada diri individu, baik itu kognitif, afentif, dan juga psikomotorik. Prayitno dan Afriva Khaidir (2011) mendefinisikan karakter sebagai sifat pribadi yang relative stabil pada diri individu yang menjadi landasan bagi penampilan perilaku dalam standar norma dan nilai yang tinggi. Merujuk kepada pendapat tersebut, karakter sesunguhnya adalah bentuk perwujudan diri individu dalam berperilaku yang sesuai dengan kaidah, tata nilai yang diakui dan dianut dimana individu berada.

Karakter berkaitan dan sering disamakan dengan moral, yaitu suatu tatanan nilai yang dianut dan dipercaya membawa kebaikan pada masyarakat disuatu daerah. Jika meninjau definisi karakter dalam kamus piskologi, karakter adalah kepribadian ditinjau dari titik tolak etis atau moral, misalnya kejujuran seseorang, dan biasanya berkaitan dengan sifat-sifat yang relatif tetap.

Nilai-nilai karakter suatu kelompok individu, pada suatu tempat bisa saja berbeda dan bisa juga sama. Hal itu disebabkan, kondisi sosiokultural, tantangan hidup, demografi yang berbeda sangat mempengaruhi perilaku dan tatanan nilai yang dianut masyarakatnya. Bagi bangsa Indonesia, nilai-nilai karakter yang terbaik adalah nilai-nilai Pancasila. Pancasila adalah pedoman hidup bangsa Indonesia, sehingga segenap perilaku bangsa Indonesia hendaknya berpedoman pada nilai-nilai pancasila. Dengan demikian, secara ringkas dimaknai bahwa karakter bangsa Indonesia sejatinya adalah karakter yang "Pancasilais". Mengembangkan karakter peserta didik adalah mengembangkan nilai-nilai Pancasila kedalam setiap perilaku peserta didik dalam kehidupannya. Pusat Kurikulum Balitbang Kemendiknas (2011) telah merumuskan nilai-nilai karakter yang harus dikembangkan pada diri peserta didik, yaitu:

Nilai-nilai karakter berlandaskan budaya bangsa
1. Religius
10. Semangat kebangsaan
2. Jujur
11. Cinta tanah air
3. Toleransi
12. Menghargai prestasi
4. Disiplin
5. Kerja keras
13. Bersahabat/komuniktif
14. Cinta damai
6. Kreatif
15. Gemar membaca
7. Mandirl
8. Demokratis
16. Peduli lingkungan
17. Peduli sosial
9. Rasa ingin tahu 
18 nilai-nilai karakter di atas harus dibangun dan dikembangkan kepada peserta didik melalui proses pendidikan. Nilai-nilai karakter tersebut harus mewarnai setiap gerak perilaku peserta didik/individu dalam proses kehidupannya. Jika diperhatikan, 18 nilai karakter tidak memiliki kecenderungan pada satu aspek tertentu (misalkan mementingkan aspek kognitif saja) melainkan sangat mementingkan segenap potensi atau dimensi yang dimiliki individu.

\section{b. Pengembangan Karakter Melalui Pelayanan Konseling}

Upaya mengembangkan karakter peserta didik melalui proses pendidikan dilakukan dengan menyisipkan nilainilai karakter dalam proses pembelajaran (oleh guru Mata Pelajaran) dan pelayanan konseling (oleh guru BK). Bagi guru Bimbingan dan Konseling, pengembangan karakter peserta didik dilakukan melalui proses pelayanan konseling yang dilakukan melalui berbagai jenis layanan. Namun, dalam hal ini difokuskan kepada layanan informasi dan bimbingan kelompok.

\section{Layanan Informasi}

Layanan informasi merupakan jenis layanan yang diberikan dalam rangka membekali peserta didik dengan berbagai informasi yang berkenaan dengan bidang pribadi, belajar, sosial, dan karir. Prayitno (2012) menyebutkan bahwa tujuan layanan informasi akan membantu peserta didik memahami dan menerima diri dan lingkungannya secara objektif, positif, dinamis; mengambil keputusan; mengarahkan diri untuk kegiatan-kegiatan yang berguna sesuai dengan keputusan yang diambil; dan akhirnya mengaktualissasikan diri secara terintegrasikan.

\section{Materi layanan}

Proses aktualisasi diri individu dalam lingkungan kehidupannya sangat membutuhkan perilaku yang mencerminkan nilai-nilai dan norma yang dianut dalam lingkungannya tersebut. Agar tercapai pola perilaku yang sesuai dengan norma dan nilai yang benar, maka guru BK sangat perlu memberikan informasi-informasi yang menjadi materi layanan informasi menyangkut:

a) Peran Individu dalam Kehidupan 
Informasi mengenai peran yang disandang individu dalam kehidupan didunia ini sangatlah besar manfaatnya. Dengan diberikan informasi mengenai berbagai peran yang disandang, individu akan secara benar memposisikan bilamana ia sedang menjadi hamba Tuhan, Sebagai "anak" dalam kehidupan keluarga, sebagai anggota masyarakat, sebagai siswa, dan peran-peran lainnya. Dengan pemahaman yang baik akan peran dan tugas dari peran tersebut, individu akan dapat hidup dengan baik dan menjadi teladan bagi orang lain. Individu yang memiliki kemampuan dan karakter seperti itulah yang diharapkan dapat muncul bagi bangsa Indonesia.

b) Hak dan Kewajiban sebagai Manusia

Permasalahan karakter peserta didik/individu saat ini terkait erat dengan dilanggarkan hak-hak orang lain, dan tidak dilaksanakannya secara optimal kewajiban individu. Oleh karena, pembekalan individu akan hak dan kewajiban yang sesuai dengan peran yang diembannya merupakan sesuatu hal yang sangat urgen. Melalui layanan informasi inilah, guru BK mengenalkan secara dini, berkelanjutan tentang hak dan kewajiban yang harus dijalani oleh peserta didik, dengan demikian dalam realita kehidupannya peserta didik akan menjalankan kewajibannya, dan menghormati hak-hak orang lain.

\section{Format Kegiatan}

Pemberian informasi terkait dengan peran individu dalam kehidupan, hak dan kewajiban yang harus dijalani menjadi bekal yang sangat penting bagi peserta didik. Materi layanan tersebut secara makro telah mencakup ke 18 unsur nilai-nilai karakter yang dirumuskan Kementerian Pendidikan.

Format kegiatan layanan informasi dalam mengembangkan karakter peserta didik, hendaknya dilakukan secara menarik, inovatif, dan kreatif. sala satu format kegiatan yang dapat dilakukan yaitu dengan format lapangan. Peserta didik dibawa dalam kehidupan yang nyata dan diminta mengumpulkan data-data terkait dengan pelaksanaan peran individu, dan juga hak dan kewajiban manusia. Lalu materi tersebut dijadikan sebagai bahan diskusi dalam kelas. Guru BK memiliki peran yang sangat besar sebagai informator, dan fasilitator dalam kegiatan ini. 
- Sebagai fasilitator; guru BK harus bisa menfasilitasi proses dan dinamika diskusi menjadi terarah dan fokus

- Sebagai Informator; guru BK diantara proses diskusi harus bisa memberikan informasi-informasi terkait dengan data dan bahan diskusi dari peserta didik, tujuannya adalah agar peserta didik memiliki pemahaman terkait dengan apa yang mereka temukan dilapangan.

\section{Layanan Bimbingan Kelompok}

Layanan bimbingan kelompok, bagi sebagian besar siswa merupakan layanan yang paling disukai. Melalui layanan bimbingan kelompok peserta didik diberikan kebebasan untuk mengekspresikan diri dan berlatih mengembangkan komunikasi dengan orang lain. Pengembangan karakter melalui bimbingan kelompok telah dirancang secara khusus oleh Prayitno dan kawan-kawan sejak tahun 2011. Pola pelaksanaannya dikenal dengan sebutan KPB-KC ( Kelompok Pengamalan Butir-Butir Karakter Cerdas). Format pelayanan diberikan non-klasikal.
Menurut Prayitno dan Afriva Khaidir (2011) pelaksanaan pengembangan karakter melalui format kelompok memiliki cirri mengembangkan dinamika kejiwaan yang sehat berkenaan dengan: spontanitas, perasaan positif, katarsis, peningkatan pengetahuan, dan peningkatan keterampilan sosial. Ciri dan keunikan proses bimbingan kelompok tersebutlah yang menjadi alasan pengembangan karakter peserta didik melalui pelayanan bimbingan kelompok lebih disukai dan diharapkan memiliki nilai efektifitas yang tinggi.

\section{Materi Layanan}

Berbeda dengan pengembangan karakter melalui layanan informasi, dimana materi telah ditetapkan oleh guru BK, dalam format bimbingan kelompok materi akan sangat baik jika peserta didik yang diberi kebebasan menentukan materi layanan (tetap mengacu kepada nilai-nilai karakter). tujuan diberikannya kebebasan dalam menentukan materi karena, anggota kelompok atau peserta didik yang lebih tahu apa yang mereka butuhkan, sehingga nantinya proses layanan 
bimbingan kelompok akan berjalan dengan dinamis dan aktif.

Materi layanan yang akan dibahas meliputi bidang kehidupan pribadi, keluarga dan kelompok, bermasyarakat, berbangsa, dan bernegara. walaupun topik yang akan dibahas diberikan kebebasan kepada anggota kelompok untuk memilihnya, namun guru BK hendaknya mampu memberikan pengarahan dan menjelaskan topik-topik mana yang lebih penting dan actual untuk dibahas dalam kelompok. Oleh karena itu, guru BK sebagai fasilitator dituntuk untuk memiliki pengetahuan yang luas, benar tentang nilai-nilai karakter. Bahkan jika merujuk kepada pendapat Prayitno dan Afriva Khaidir (2011), kandungan yang harus dimiliki oleh guru BK sebagai fasilitator pengembangan karakter melalui layanan bimbingan kelompok adalah sebagai berkut:

1) Menguasai nilai-nilai karaktercerdas, termasuk didalamnya nilai-nilai luhur Pancasila

2) Memiliki pengetahuan yang luas, khususnya tentang butir wujud pengamalan Pancasila, UUd 1945 dan kaidah hukum serta peraturan yang berlaku
3) Memiliki pengetahuan tentang dinamika kelompok dan mampu membina serta mengarahkan kegiatan kelompok

4) Terbuka kepada pendapat yang berbeda, kritik dan saran yang berkembang dalam kelompok

5) Mampu memberikan pengarahan yang tepat berkenaan dengan nilai-nilai karater-cerdas

6) Mampu menampilkan diri secara wajar, simpatik, dan memiliki rasa humor

\section{Format Kegiatan}

Layanan bimbingan kelompok sangat menekankan dinamika kelompok. Proses menjadi acuan pokok dalam penyelenggaraan layanan ini, sehingga peran guru BK sebagai pemimpin kelompok sangat penting. format kegiatan bimbingan kelompok yang dilakukan menurut Prayitno (2012) melalui beberapa tahapan yaitu sebagai berikut:

a) Tahap Pembentukan

Tahap ini merupakan tahap pengenalan, tahap melibatkan diri atau proses memasuki diri ke dalam kehidupan kelompok. Variasi dalam hal jenis kelamin, 
unsur pendidikan dan pengalaman

menjadi pertimbangan dalam

pembentukan kelompok.

b) Tahap Peralihan

Pada tahap ini pemimpin kelompok menjelaskan peranan para anggota kelompok dalam kelompok.Kemudian pemimpin kelompok menawarkan apakah para anggota sudah siap memulai kegiatan.Tahap peralihan merupakan ‘jembatan' antara tahap pembentukan dan kegiatan..

c) Tahap Kegiatan

Tahap ini merupakan kehidupan yang sebenarnya dari kelompok. Namun kelangsungan kegiatan kelompok pada tahap ini amat tergantung pada hasil dari kedua tahap sebelumnya. Pada tahap ini membahas topik yang telah ditentukan. Seluruh peserta kelompok berperan aktif dan terbuka mengemukakan pikiran dan pendapatnya terkait topik yang dibahas dalam kelompok. Pada tahap ini, hubungan antar anggota kelompok tumbuh dengan baik dan pada tahap ini topik dibahas secara mendalam, luas dan tuntas. Sehingga wawasan, pengetahuan, dan nilai yang tertanam dalam diri tiap anggota kelompok semakin baik.

d) Tahap Penyimpulan Tahap penyimpulan yaitu tahapan untuk melihat kembali apa yang sudah dilakukan dan dicapai oleh kelompok. Peserta kelompok diminta melakukan refleksi berkenaan dengan kegiatan pembahasan yang baru saja mereka ikuti.

e) Tahap Pengakhiran

Tahap pengakhiran ini adalah tahap yang harus terjadi pada saat yang dianggap tepat. Pada tahap ini dibahas terkait frekuensi pertemuan kelompok dan juga pembahasan keberhasilan kelompok.

Seperti pengembangan karakter peserta didik melalui layanan informasi, pengembangan karakter melalui format layanan bimbingan kelomok akan sangat efektif jika dilakukan secara berkelanjutan dan terprogram. Hal ini dilandasi oleh asumsi bahwa pengembangan karakter bukan hanya sekedar memberikan pemahaman namun juga proses pembiasaan. 


\section{KESIMPULAN DAN SARAN}

\section{a. Kesimpulan}

1. Pengembangan karakter pada prinsipnya adalah menciptakan individu yang mampu berperilaku secara konsisten sesuai dengan norma dan nilai-nilai yang berlaku dalam kehidupan masayarakat.

2. Nilai karakter yang luhur bagi bangsa Indonesia bersumber dari nilai-nilai Pancasila

3. Pengembangan karakter peserta didik dapat dilakukan oleh guru BK melalui format layanan Informasi dan bimbingan kelompok

\section{b. Saran}

Guru BK merupakan figure utama dalam proses pengembangan karakter peserta didik melalui pelayanan bimbingan konseling, oleh karena itu disaran kepada guru BK agar:

1. Meningkatkan kompetensi dan kapabilitasnya dalam penyelenggaraan layaan informasi dan bimbingan kelompok
2. Memahami, menguasai, dan juga mengamalkan nilai-nilai Pancasila dan UUD 1945 secara konsisten dalam kehidupannya.

3. Terbuka terhadap informasi dan perkembangan teknologi, hal ini dikarenakan permasalahan karakter peserta didik erat kaitanya dengan kemajuan jaman dan teknologi.

\section{DAFTAR PUSTAKA}

\begin{tabular}{cc} 
Pusat & \multicolumn{2}{c}{ Kurikulum Departemen } \\
& Pendidikan Nasional. 2011. \\
Bahan Pelatihan Penguatan \\
Metodologi $\quad$ Pembelajaran \\
Berdasarkan \\
Budaya untuk Membentuk \\
Daya Saing dan Karakter \\
Bangsa. Jakarta: Kemendiknas
\end{tabular}

Nurul Zuriah. 2011. Pendidikan Moral \& Budi Pekerti dalam Perspektif Perubahan. Jakarta: Bumi Aksara

Prayitno.2012. Jenis Layanan dan Kegiatan Pendukung Konseling. Padang : PPK UNP

Prayitno dan Afriva Khaidir.2011. Model Pendidikan KarakterCerdas. Padang: UNP Press 